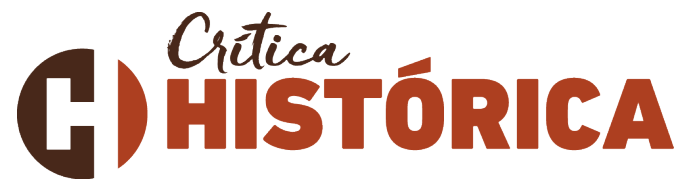

\section{O caminho percorrido pela diocese de Propriá-SE até a redemocratização do país (1964-1985)}

\author{
The path followed by the diocese of Propriá-SE untill the redemocratization of the \\ country (1964-1985)
}

\section{Osnar Gomes dos Santos*}

Resumo: Este artigo tem por objetivo analisar o caminho cíclico trilhado pela diocese de Propriá-SE até a redemocratização do país; desde o início do seu processo, então desencadeado pela política de distensão da ditadura firmada pelo general Ernesto Geisel. A análise sobre a diocese de Propriá-SE pode oferecer uma compreensão luminosa acerca das distintas atuações da Igreja Católica no Brasil durante a ditadura militar. Além de esclarecer os seus múltiplos comportamentos no período marcado pela redemocratização no Brasil. Estimulado por estes requisitos, o estudo que segue apresenta um breve diagnóstico do processo circular da diocese de Propriá-SE entre o início e o fim da ditadura militar.

Palavras-chave: Diocese de Propriá-SE, ditadura, redemocratização.

Abstract: The purpose of this article is to analyze the cyclical path trodden by the diocese of Propriá-SE until the redemocratization of the country, since the beginning of his process, then triggered by the policy of distension of the dictatorship established by general Ernesto Geisel. The analysis of the diocese of Propriá-SE can offer a bright understanding about the different performances of the Catholic Church in Brazil during the military dictatorship. In addition to clarifying their multiple behaviors in the period marked by the redemocratization in Brazil. Stimulated by these requirements, the study that follows presents a brief diagnosis of the circular process of the diocese of Propria-SE between the beginning and the end of the military dictatorship.

\footnotetext{
Doutorando em História pelo Programa de Pós-Graduação em História da Universidade Federal de Pernambuco.
} 
Keywords: Diocese of Propriá-SE, dictatorship, redemocratization.

\section{O encontro entre o "conservadorismo reformista" da diocese de Propriá-SE e a “modernização conservadora” do bloco de poder do capital multinacional e associado}

A diocese de Propriá ilustra um caso específico do percurso trilhado pela Igreja Católica no Brasil durante o período da ditadura militar. Situada ao norte do Estado de Sergipe, em região marcada pela concentração de terras e localizada no polígono da seca, pelos estudos de Roberto Eufrásio, a diocese apresentava, até meados da década de 1970, uma situação econômica em que apenas I0\% das terras boas para a agricultura estavam nas mãos de 70\% dos proprietários (OLIVEIRA, 2006, p. 9I). Portanto, mais da metade da população sem possuir "um palmo de terra" (ibidem). Seus procedimentos durante a ditadura precisam ser analisados minuciosamente para captar a circularidade complexa que findou por transportar a instituição ao processo de redemocratização do país, com uma feição significativamente distinta dos anos iniciais da ditadura.

Após um longo caminho de mudanças cíclicas nas disposições da diocese de Propriá na esfera política, a instituição religiosa se sublinhou no processo de redemocratização do país no campo da oposição à ditadura instaurada a partir do golpe de Estado no ano de 1964. Importa salientar que a diocese de Propriá contribuiu para a legitimação do golpe empreendido pelo bloco de poder que estimulou a oposição sistemática ao governo reformista de João Goulart. Dentre os segmentos que faziam parte daquele bloco de poder, nas palavras do historiador René Dreifuss, destacava-se a elite orgânica do capital multinacional e associado (DREIFUSS, I98I, passim), interessada, sobremaneira, na derrubada da plataforma política de Jango.

Para tanto, tal elite orgânica promoveu campanhas que tinham por objetivo criar um clima de desestabilização política no país. Um dos principais métodos utilizados para alcançar o intento foi flertar intensivamente com a chamada "indústria do anticomunismo". De acordo com o pesquisador Rodrigo Sá Motta, a "indústria do anticomunismo" foi utilizada como uma espécie de "manipulação oportunista do medo" (MOTTA, 2002, p. 72). Parcela substantiva da Igreja Católica foi atraída pela agenda golpista sem muita resistência. Inclusive, em concordância com Dreifuss, religiosos, leigos e intelectuais católicos eram figuras centrais a serem cooptadas pelo bloco de poder que almejava uma "modernização conservadora" em substituição da plataforma trabalhista de 
Goulart, com o único objetivo de subtrair importantes segmentos do catolicismo do campo nacional-reformista (DREIFUSS, I98I, p. 236). A combinação entre esses pontos pode ser resumida assim, seguindo as palavras de Dreifuss:

A ação da elite orgânica empresarial deve ser considerada como a praxe de um bloco burguês de poder, premeditada e cuidadosamente amadurecida durante vários anos. Trazendo à tona a dimensão orgânica e a dinâmica envolvidas (situação, posição e ação de classe), pode-se perceber a evidência histórica do emergente bloco de poder multinacional e associado forjando a sua própria forma de Estado. O que ocorreu em abril de 1964 não foi um golpe militar conspirativo, mas sim o resultado de uma campanha política, ideológica e militar travada pela elite orgânica centrada no complexo IPES/IBAD (DREIFUSS, I98I, p. 23I).

O bispo da diocese de Propriá foi atraído pelo clima de tensão estimulado pelo bloco de poder oposicionista e externou sua posição sobre o governo Jango em diversas publicações do principal órgão informativo da diocese de Propriá, o jornal A Defesa. Talvez tenha sido a mais famosa delas, por se tratar de um manifesto de saudação pelo exitoso golpe de Estado, a publicação em que o bispo dom José Brandão de Castro exalta a ação dos militares que assumiram o poder logo após o citado golpe de abril de 1964. Por ela, dom Brandão reafirmou seu compromisso com as forças que derrubaram João Goulart, demonstrando otimismo diante da assunção do novo regime. Para o bispo, era o sinal de que "o poder tinha saído das mãos dos [adeptos do bloco de poder nacional-reformista] que estavam para lançar-nos na órbita de Moscou e Pequim". . Ademais, a diocese de Propriá, duas semanas após o golpe, saúda as Forças Armadas e as famosas "Marchas da família com Deus pela liberdade", que segundo o informativo diocesano, se multiplicavam pelo país. Na avaliação de A Defesa, o regozijo diante da deposição de Goulart era explicado da seguinte forma:

A alegria é justa. Dias tremendos nos aguardavam. As coisas estavam se encaminhando para um golpe rubro-ditatorial, que transformaria o Brasil numa nova Cuba, com "paredon" e tudo. O barril de pólvora estava prestes a explodir. Aproximava-se a erupção vulcânica. Antes não se acreditava no que agora se vê. Gastaram muitos bilhões com propaganda comunista.

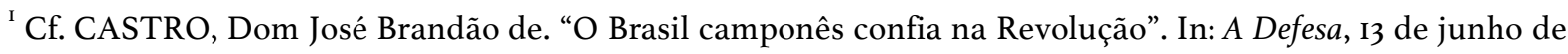
I964, p. I.
} 
Havia russos, chineses e cubanos, especialistas em guerrilhas, trabalhando para a bolchevização do Brasil, derramando dólares e também metralhadoras aos milhões. Havia muita gente condenada à morte [...]. Marcha da Família. A família brasileira é essencialmente cristã. Crê em Deus. Não topa com o ateísmo. É espiritualista. Não topa com o materialismo crasso. Para que força-la? [...]. Pátria livre do Credo Vermelho e de sua prole macabra [...]. ${ }^{2}$

Lendo a publicação, clarifica-se a nítida inserção da diocese na onda anticomunista que permeou o ideário de setores do clero católico. Além disso, vislumbra-se no artigo a exaltação das "marchas da família", tão responsáveis pelo caldo legitimador do golpe em iminência deixado para a ação dos militares. Estes últimos, junto de forças civis nacionais e internacionais, diante do sucesso das marchas, viram sua empreitada conspiratória de assalto ao poder se sair fortalecida. Não à toa, o historiador Boris Fausto usou a sentença "sinal de tempestade", a fim de realçar o significado para o governo das marchas que varriam o país (FAUSTO, I995, p. 460). Em suma, uma perda desastrosa de capital político da plataforma nacional-reformista capitaneada por Goulart. Vale ressaltar que as marchas passaram também por Sergipe, com especial manifestação em municípios acoplados pela diocese de Propriá, a exemplo das cidades de Japoatã, Aquidabã, Cedro de São João e a cidade sede da diocese, Propriá. ${ }^{3}$

Ademais, a diocese de Propriá promoveu o programa filantrópico estadunidense “Aliança para o Progresso". De acordo com Vicente Gil da Silva, a filantropia da "Aliança” acobertava interesses estratégicos do governo Kennedy no continente latino-americano (SILVA, 2008, p. 30). Segundo pesquisa de José Carlos Teixeira, a diplomacia estadunidense só fornecia alimentos e recursos aos estados brasileiros que expressavam uma evidente oposição ao governo de João Goulart (TEIXEIRA DA SILVA, I990, p. 364). Esse é um bom exemplo dos limites da "ajuda humanitária” dos Estados Unidos naquele contexto. A diocese, entretanto, segundo seu órgão informativo principal, saudava as "benesses" levadas pelo programa que objetivou erguer uma alternativa assistencialista no lugar de uma ampla agenda reformadora das estruturas sociopolíticas. ${ }^{4}$

Com a conflagração do golpe militar, o jornal A Defesa chamou de "solução cristã e democrática" as ações do novo regime no campo social e econômico. Mais do que isso,

\footnotetext{
${ }^{2}$ FORÇA das forças - O terço. In: A Defesa, I5 de abril de i964, p. I.

${ }^{3}$ Cf. CASTRO, Dom José Brandão de. "O Brasil camponês confia na Revolução". In: A Defesa, I3 de junho de I964, p. I.

${ }^{4}$ Cf. REALIZAÇÕES materiais sob a Aliança para o Progresso. In: A Defesa, 30 de maio de i964, p. I.
} 
citou Sebastião de Holanda Cavalcanti, importante industrial pernambucano, diretortesoureiro da Federação das Indústrias de Pernambuco (FIEPE), a fim de ressaltar que "empresários e operários se entendem" e, assim sendo, salientar que "uma nova fase foi aberta nas relações entre as classes empresariais e os trabalhadores".

Lendo o artigo na íntegra, alguns pontos chamam a atenção. Dentre eles, a citação da encíclica social Mater et Magistra, com a finalidade de realçar os "interesses em comum" entre patrões e empregados. Pontuar "interesses em comum" entre empregadores e empregados se constituía enquanto um dos pontos mais ensejados pela tática política do sinistro complexo Ipes/Ibad (Instituto de Pesquisas e Estudos Sociais/Instituto Brasileiro de Ação Democrática), corresponsável pela conspiração que abatera as forças reformistas em 1964. Enquanto o Ibad se portava na condição de um "grupo de pressão", o Ipes coordenava toda a ação golpista. Numas poucas palavras, o teórico José Paulo Netto assim resume o Ipes:

O Ipes não foi uma entidade episódica, construída somente para desestabilizar o governo Jango: estruturada com rigor, operando planejadamente, pretendia ser - e foi - uma espécie de "Estado-maior" das classes dominantes e seus associados estrangeiros; constituiu, de fato, o centro estratégico de formulação e intervenção política do empresariado brasileiro [...]. Com vários departamentos especializados, o Ipes produzia relatórios, acompanhava a conjuntura econômica e política, formulava projetos, divulgava matérias para os veículos de comunicação, providenciava publicações - esta a sua face pública [...]. Mas havia outra face, conspirativa, oculta [...] (NETTO, 20I4, p. 50).

Era também uma das metas do Ipes a publicação de materiais a fim de promover a encíclica social Mater et Magistra, com dois objetivos, de acordo com Dreifuss: (I) proporcionar a opinião pública uma mensagem suficientemente ampla para favorecer a plataforma político-econômica do novo regime; e (2) indispor o público contra o socialismo, o comunismo e o nacional-reformismo (DREIFUSS, I98I, p. 236). Como se vê, os interesses do Ipes sobre a encíclica social produziram frutuosos resultados para a intelligentsia do bloco de poder oposicionista. Exemplo disso foi a notável adesão do clero diocesano ao objetivo buscado pelo Ipes em unificar as pautas da Mater et Magistra e da

\footnotetext{
${ }^{5}$ Cf. SOLUÇÃO cristã e democrática. In: A Defesa, 30 de abril de 1964, p. I.
} 
"modernização conservadora" ${ }^{6}$ da elite orgânica do capital multinacional e associado, a qual organizava nas sombras o ideário das forças que então assaltavam o poder executivo.

Ainda que a diocese de Propriá defendesse reformas estruturais no país, ${ }^{7}$ àquela altura o seu reformismo moderado foi atraído com eficácia pela estratégia do bloco de poder responsável pelo golpe militar então desencadeado. Naquele momento, o conservadorismo católico era imprescindível para a "guerra psicossocial" estimulada pela conspiração golpista. Assim como a retirada do governo Goulart era indispensável, sob o ponto de vista dos grupos conservadores católicos, para garantir a "solução cristã e democrática". Ambos os lados viam-se como personagens centrais na luta contra o "perigo vermelho". O fim do artigo publicado pela Defesa ilustra precisamente a simbiose entre os interesses da diocese e os objetivos dos representantes das associações das "classes produtoras" - a exemplo da FIEPE de Sebastião Cavalcanti -, lidas na publicação enquanto "os homens de empresa". Diz a nota final:

Integrados na "Mater et Magistra" e defendendo-lhe os pontos de vista, os homens de empresa estão dando a sua contribuição para a solução cristã e democrática dos problemas sociais e econômicos com que se vê a braços o Brasil (Grifo nosso). ${ }^{8}$

Estava, portanto, claro e cristalino o caráter amistoso, descrito na publicação da Defesa, que norteou grupos distintos ao encontro de motivos em comum com a finalidade de fomentar a oposição ao trabalhismo janguista e à sua plataforma nacional-reformista.

\footnotetext{
${ }^{6}$ De acordo com Rodrigo Sá Motta, o conceito de modernização conservadora pode servir como síntese dos paradoxos e contradições da ditadura militar instaurada após o golpe. Era interesse da ditadura expressar, simultaneamente, impulsos conservadores e modernizantes. $O$ desejo modernizador implicava desenvolvimento econômico e tecnológico [...], além de expansão industrial e mecanização agrícola. Com isso, para Motta, levava-se ao aumento da urbanização e do operariado fabril, gerando potenciais tensões e instabilidade nas relações sociais e de trabalho. Já o impulso conservador estava ligado à vontade de preservar a ordem social e os valores tradicionais, o que insuflava o combate às utopias revolucionárias e a outras formas de "subversão". Em sua conclusão final, Rodrigo Sá Motta definiu a modernização proposta pela nova ordem na condição de conservadora e autoritária. Ver: MOTTA, Rodrigo. A modernização autoritário-conservadora nas universidades e a influência da cultura política. In: AARÃO REIS, Daniel et al. A ditadura que mudou o Brasil: 50 anos do golpe de 1964. Rio de Janeiro: Zahar, 2014.

${ }^{7}$ Era de conhecimento público o trabalho da Ação Social da Diocese de Propriá (ASDIP) e dos seus cinco departamentos. Visavam atender desde necessidades básicas dos mais pobres até atividades culturais para os jovens. A diocese também defendia reformas educacionais para erradicar o analfabetismo e a formação de sindicatos agrários para dirimir a pobreza e a desigualdade na região, amparados pelas encíclicas sociais do papa João XXIII. A título de exemplo, conferir entrevista em que o bispo dom Brandão chama de "imperiosa" a necessidade de uma reforma agrária no Nordeste. Apud "O bispo de Propriá fala ao jornal 'Senhor Bom Jesus"”. In: A Defesa, I5 de novembro de I96I, p. 3. Diante disso, pode-se dizer que a diocese exibia traços do que se pode chamar de "conservadorismo reformista". Era de amplo interesse do bloco de poder de oposição a Goulart atuar junto daqueles grupos que compartilhavam traços de um "conservadorismo reformista".

${ }^{8}$ Cf. SOLUÇÃO cristã e democrática. In: A Defesa, 30 de abril de i964, p. I.
} 


\section{Da colaboração ao conflito}

Difícil acreditar na virada político-eclesial radical que se fez presente em parte considerável de setores da Igreja Católica que colaboraram com o bloco de poder de oposição a João Goulart. Ainda mais difícil acreditar nas mudanças ocorridas na diocese de Propriá, contumaz opositora de Jango e aliada das forças políticas e sociais que contribuíram para a desestabilização do país - elas nacionais e internacionais, como já pontuado neste artigo - durante a ditadura militar. Mudanças que, a princípio, sinalizavam um comportamento moderadamente crítico, mas que findou por ser um dos mais emblemáticos exemplos da oposição sistemática da Igreja Católica à ditadura militar até os momentos em que esta agonizava.

Suas posições, já partir do ano de I966, refletiam uma postura dúbia, revelando uma mescla entre adesão e a citada crítica moderada ante a nova ordem estabelecida pelo conluio empresarial-militar. Foi assim que, naquele ano, a diocese se colocou em defesa de membros da Ação Católica Brasileira (ACB). Segundo pesquisa de Isaías Nascimento, estes últimos eram acusados de "agitadores comunistas", em razão de suas defesas a trabalhadores urbanos e rurais do Nordeste (NASCIMENTO FILHO, 20I7, 8I). Para Isaías Nascimento, a defesa da diocese aos membros da ACB exemplificava os primeiros sinais de distanciamento da instituição diante da ditadura militar (ibidem).

É preciso lembrar, entretanto, a dubiedade de tal postura. A princípio, na chegada do primeiro ano do golpe, em fevereiro de 1965, publicações da Defesa demonstravam alinhamento evidente com o novo regime, dado o espaço deixado para pronunciamentos, informações gerais e detalhamentos da administração pública do marechal Castelo Branco, então presidente do país. A título de exemplo, a matéria "Eu não tenho vocação para ditador", publicada durante a polêmica em torno do adiamento das eleições diretas, é sintomática. Citando um jornalista pernambucano, não identificado na matéria, o jornal sublinhou possíveis justificativas para o adiamento das eleições, com o propósito de acalmar os ânimos daqueles que suspeitavam das intenções do novo regime. ${ }^{9}$

No ano de 1966, depois das defesas aos membros da ACB, o tom sobre política era notadamente moderado, nada semelhante aos alardes proferidos contra os partidários do regime deposto. Exemplo disso se expressou na nota de celebração ante o recebimento de um diploma de sócio benemérito concedido pela entidade filantrópica Sociedade União Beneficente ao governador-interventor de Sergipe, Lourival Baptista - então eleito ao

\footnotetext{
${ }^{9}$ Cf. "Eu não tenho vocação para ditador". In: A Defesa, I4 de fevereiro de i965, p. I.
} 
governo naquele ano -, o qual possuía ligações com uma das frentes orgânicas do Ibad, a pouco sútil Ação Democrática Parlamentar (ADP). Esta financiava políticos no pré-golpe com a intenção de criar um núcleo duro de oposição parlamentar a João Goulart. O perfil do então governador Lourival Baptista foi assim descrito pelo historiador Ibarê Dantas:

Deputado federal em duas legislaturas (1959-1962 e I963-1967),
especialmente na última, ampliou a confiabilidade junto aos
conservadores pelas suas intervenções contra as reformas de base,
identificou-se com a campanha pela derrubada do governo Goulart [...].
Apesar de indicado pelo marechal Castelo Branco [...] não gozava de muita
simpatia pelo seu comportamento político. Entretanto, pragmático,
esmerou-se em servir à ordem autoritária com desenvoltura [...]
(DANTAS, 20I4, p. II4-II5).

A ADP não comportava qualquer tipo de figura política. Dos membros que compunham os quadros da ADP, segundo Dreifuss, destacavam-se políticos conservadores e reacionários, na maior parte membros dos partidos UDN e PDS. É importante ressaltar que a ADP era um bloco multipartidário criado, sobretudo, para estabelecer a presença política do complexo Ipes/Ibad no Congresso e, assim, permitir à elite orgânica do capital multinacional e associado a, consoante às documentações apresentadas por Dreifuss, "imiscuir-se na política nacional e a moldar a opinião pública através de mais um importante canal" (DREIFUSS, I98I, p. 320).

Lourival Baptista, integrado à União Democrática Nacional (UDN) até o fim do pluripartidarismo - encerrado após o Ato Institucional Número 2 (AI-2) - filiou-se ao partido oficial do novo regime, a Aliança Renovadora Nacional (ARENA). Obstinado crítico das reformas de base e, posteriormente, arenista representante do regime instaurado no pós-golpe, esta era a figura pública condecorada em 1966 por seus "relevantes serviços prestados" à Sociedade União Beneficente. Três anos depois, seria ele congratulado pela diocese com o diploma de "Honra ao Mérito", novamente pelos "relevantes serviços prestados", desta vez, à Ação Social da Diocese de Propriá. ${ }^{\text {Io }}$

Ademais, a diocese de Propriá celebrou por muitos anos após o golpe os chamados “aniversários da Revolução de I964". No ano de I972, a comemoração do oitavo ano da dita "Revolução de 64", foi celebrado com inaugurações, a exemplo do Mercado de abastecimento de cereais, do Colégio diocesano de Propriá, do Escritório do Fundo de

\footnotetext{
${ }^{\text {Io }}$ GOVERNADOR Lourival Baptista será homenageado. In: A Defesa, 25 de novembro de I969, p. I.
} 
Assistência e Previdência do Trabalhador Rural (FUNRURAL) e do edifício do Instituto Nacional da Previdência Social (INPS). Todas as inaugurações contaram com a participação de autoridades locais e, no caso específico da inauguração do edifício do INPS, com a benção litúrgica do bispo dom José Brandão de Castro. ${ }^{\text {II }}$

Para além dessas questões, uma das mais emblemáticas sintonias da diocese frente ao establishment foi revelada com as diversas chamadas públicas para o Sesquicentenário da Independência. Era uma comemoração inventada pela nova ordem para celebrar os I5O anos da Independência do Brasil. O objetivo era claro: legitimar a ditadura em vigor, mediante o ufanismo generalizado provocado pelos atos solenes do evento. ${ }^{\mathrm{I} 2}$ Nesse sentido, as passagens do artigo de Antônio Condes Dias, estimado leigo católico e jornalista sergipano de destaque, ilustram precisamente as imagens lançadas por importantes segmentos da diocese sobre o Sesquicentenário. Conforme o artigo:

Passou o tempo em que o povo pouco entendia de civismo e de amor pátrio, porque andava meio descrente das coisas e um tanto desencantado de certos homens públicos que só visavam seus interesses e ambições. Vivia o povo quase alimentado de tiradas demagógicas e de promessas eleitoreiras. Felizmente tudo vem mudando para melhor de 1964 para cá. Andamos agora em ritmo de Brasil Grande. Deixou [...] de ser gigante eternamente adormecido em leito magnífico para tornar-se a nação que marcha a passos largos, em busca de um destino promissor. Isso de dizerse que o Brasil é o país do futuro já não se justifica. Vivemos agora em termos do presente com as grandiosas realizações governamentais em benefício do povo. Temos um governo sério que trabalha pelo progresso do país. ${ }^{13}$

As relações amistosas da diocese com as autoridades políticas no âmbito local e nacional pareciam evidentes. Contudo, não se pode menosprezar a autonomia da diocese no campo político. No ano de 1969, por exemplo, o lançamento da declaração da Comissão Central da Conferência Nacional dos Bispos do Brasil (CNBB), sobre a situação atual do país, ganhou relevante espaço no jornal diocesano. A defesa pelo retorno da normalidade jurídica, assinalada no documento, traduzia uma crítica explícita aos descalabros

\footnotetext{
${ }^{\text {II }}$ Conferir matéria "Comemorada a Revolução de 64". In: A Defesa, II de abril de I972, p. 3.

${ }^{12}$ Sobre o Sesquicentenário, conferir: ALMEIDA, Adjovanes. O regime militar em festa: a comemoração do Sesquicentenário da Independência brasileira (1972). Doutorado em História. Universidade Federal do Rio de Janeiro. Rio de Janeiro, 2009.

${ }^{13}$ Cf. DIAS, Antônio Conde. "Evento significativo". In: A Defesa, 03 de setembro de I972, p. 2.
} 
praticados pela nova ordem - leia-se, uma nítida ditadura militar respaldada por instâncias civis -, então avolumados após a emissão do Ato Institucional Número 5 (AI-5). ${ }^{\mathrm{I}}$ Além disso, denúncias de torturas e mortes e o clamor pelo "funcionamento normal" do Legislativo e Judiciário externavam a desaprovação de setores da Igreja com os tortos percursos da ditadura instaurada. ${ }^{15}$

Um dos pontos mais interessantes da nota da Comissão da CNBB dizia respeito exatamente à autonomia da Igreja frente aos governos e regimes políticos. Esse ponto ratifica a tese de pesquisadores que analisam a religião na condição de fenômeno histórico e social que reage de acordo com critérios morais e religiosos, e não apenas reflete disposições geradas por outros fenômenos. ${ }^{16}$ Todavia, tal tese não obscurece os reflexos que outros fenômenos - como o da política e da economia - exercem na religião. Apenas recusa uma sobrevalorização desses reflexos na análise das escolhas feitas por padres, freiras, leigos etc. Noutras palavras, distintas motivações - internas e externas - podem produzir modificações na identidade de uma dada religião.

No caso da diocese de Propriá, a defesa pelo golpe político em I964 não impediu a instituição de dar continuidade à defesa por reformas estruturais e os seus conchavos com o ideário da ditadura não expressavam uma adesão completa aos valores pleiteados pela nova ordem. Em 1970, por exemplo, padres de origem belga que atuavam na diocese de Propriá eram acusados de comunistas por autoridades locais. O bispo dom Brandão saiu rapidamente em defesa dos padres, revelando-se consternado com as injúrias proferidas contra as atividades sacerdotais que estes cumpriam. ${ }^{17}$ Portanto, o suposto entrelaçamento com o establishment deve ser problematizado.

Alguns meses antes, A Defesa noticiou, em uma de suas colunas, o assassinato do padre Antônio Henrique Pereira Neto, a quem chamou de "grande sacerdote", numa pequena homenagem. ${ }^{18}$ Contudo, sublinhou sua confiança no inquérito a ser realizado sobre o motivo da morte. A diocese demonstrava cautela nas críticas à nova ordem, mantinha-se ligada à ela. Buscava ressaltar suas posições, quando destoantes, mediante altas doses de meticulosidade. Nesse sentido, a diocese de Propriá se assemelhava ao

\footnotetext{
${ }^{14} \mathrm{O}$ AI-5 retirava a máscara que, desde o golpe de 1964 , objetivava encobrir o caráter eminentemente autoritário do novo regime. Sobre o AI-5, ver: REZENDE, Maria. A ditadura militar no Brasil: repressão e pretensão de legitimidade: 1964-1984. - Londrina: Eduel, 2013.

${ }^{15}$ EPISCOPADO lança declaração sobre a situação atual. In: A Defesa, II de outubro de I969, p. I.

${ }^{16}$ Conferir, por exemplo: MAINWARING, Scott. Igreja Católica e política no Brasil (I9I6-1985). São Paulo: Brasiliense, 2004; LÖWY, Michael. A guerra dos deuses: religião e política na América Latina. Petrópolis: Vozes, 2000.

${ }^{17}$ Cf. CASTRO, Dom José Brandão de. "Os padres estrangeiros”. In: A Defesa, 28 de janeiro de i970, p. I.

${ }^{18}$ PADRE Antônio Henrique. In: A Defesa, o6 de julho de I969, p. 2.
} 
posicionamento adotado por parte considerável da hierarquia da Igreja Católica no país. Esta foi, a princípio, de acordo com Michael Löwy:

[...] bastante cuidadosa, simultaneamente disposta a cooperar com o governo militar, mas favorável a um retorno gradual à ordem constitucional. Mesmo após o assassinato de um padre, Henrique Pereira Neto, conselheiro dos estudantes católicos em Recife, em maio de 1969, e as notícias terríveis sobre torturas infligidas a religiosos [...] e a freiras presos, os bispos relutavam em tomar uma posição contra o regime (LÖWY, 2000, p. I42).

Sem dúvidas, um quadro notadamente complexo. Como se percebe, a diocese viveu situação semelhante ao clero de países que experimentaram a arbitrariedade das ditaduras. Tal situação pode ser resumida na famosa máxima do "entre a cruz e a espada". As movimentações no interior da Igreja Católica, a partir do encerramento do Concílio Vaticano II, também contribuíram para uma cada vez mais destacada autonomia da Igreja no Brasil diante da nova ordem. A começar pelo impacto causado, nas mais variadas dioceses do país, em decorrência dos acordos traçados por diversos sacerdotes no "Pacto das Catacumbas". Sobre o pacto, de acordo com José Oscar Beozzo, pode-se dizer que representou um caminho de "conversão" e de compromisso pessoal com os pobres para os mais de quinhentos bispos que foram, paulatinamente, assumindo as suas pautas. Ademais, aqueles bispos passaram a procurar sensibilizar padres e leigos para os dilemas socioeconômicos prejudiciais aos mais pobres (BEOZZO, 20I5, p. 9-IO).

Além disso, é também durante o Concílio Vaticano II que se estimulou a realização de conferências episcopais na América Latina. Segundo João Batista Libânio, a iniciativa surgiu por desejo do próprio papa Paulo VI, sensibilizado pela percepção da necessidade de conscientizar a Igreja da América Latina. Contudo, Libânio concluiu assim o seu raciocínio: "O que o Papa Paulo VI não pôde supor é que [...] estava empurrando a Igreja para rincões insuspeitados. Pensou uma coisa, e o resultado superou-a de longe e até mesmo além de sua capacidade de prever" (LIBÂNIO, 2000, p. I26).

Dito isso, em agosto de 1968, foi aberta a Segunda Conferência Geral do Episcopado Latino-Americano, conhecida como Conferência de Medellín. A condenação às "tremendas injustiças sociais" ${ }^{19}$ presenciada no evento episcopal balançou

\footnotetext{
19 Cf. CONCLUSÕES DE MEDELLÍN. II Conferência do Episcopado Latino-americano. - São Paulo: Paulinas, I968, Capítulo I4, Tópico I.
} 
substancialmente o catolicismo na América Latina. É preciso dizer que a recepção das chamadas "conclusões de Medellín" se deu de maneira distinta entre religiosos e leigos, além de não contemplar toda a hierarquia. ${ }^{20}$ No entanto, seus impactos foram sentidos por uma gama considerável de religiosos e leigos, assim como serviu de ainda maior estímulo para aqueles que acumulavam reticências ante os governos arbitrários que, até então, eram louvados. A diocese de Propriá se situa neste último caso.

Fato bastante elucidativo ocorreu nas comemorações pelos 250 anos da criação da Paróquia de Propriá. Celebrações foram realizadas na cidade contando com ampla participação popular e com a presença de autoridades políticas do Estado de Sergipe e da alta hierarquia da Igreja Católica - incluindo o núncio apostólico no Brasil, Dom Sebastião Baggio. A presença do arcebispo de Olinda e Recife, dom Helder Câmara, nas comemorações e a consequente repercussão provocada pela aberta defesa da reforma agrária feita pelo arcebispo, em frente das autoridades públicas, revelam um alinhamento cada vez mais profícuo entre a diocese de Propriá e a arquidiocese de Olinda e Recife. Esta suscitava, desde o pré-golpe de 1964, desconfiança generalizada no bloco de poder que passou a exercer o domínio político no país após abril daquele ano. ${ }^{2 \mathrm{I}}$

Embora o pronunciamento de dom Helder fosse feito sob os auspícios da prudência, falando inclusive em uma necessária cooperação com o regime, o tom era de insatisfação com os rumos da reforma agrária no país. Uma pauta cara para aqueles que aderiram ao "Pacto das Catacumbas" e participaram de Medellín, mas pouco compreendida, quando não taxada de "subversiva", pelas autoridades políticas e por setores da sociedade civil. Isso explica, mais uma vez, a insubordinação relativa de setores do clero católico diante dos procedimentos da ordem política. Crescendo de modo cíclico, com avanços e recuos, a citada insubordinação clerical pode ser ilustrada em outros muitos episódios.

Bem significativo um destes episódios. No caso específico da diocese de Propriá, alguns meses depois de convocar por meio da Defesa o Sesquicentenário da Independência, o bispo dom José Brandão de Castro assinou o que até os dias atuais se subscreve como um dos documentos mais radicais da história da Igreja Católica em favor da denominada, pelos seus assinantes, "classe dominada". Esta, para eles, deveria se "libertar" da servidão no sistema capitalista através de longa caminhada "em favor da

\footnotetext{
${ }^{20}$ A esse respeito, conferir: DUARTE, Luciano. A Igreja às portas do ano 20oo. - Aracaju: Secretaria de Estado da Cultura e Meio Ambiente, 1989.

${ }^{21}$ Conferir discurso de dom Helder nas comemorações pelos 250 anos da Paróquia de Propriá na matéria: PREGAÇÃO feita por D. Helder Câmara em Propriá, a 20-Io-68. In: A Defesa, 22 de novembro de I968, p. 3. Sobre a trajetória do arcebispo de Olinda e Recife, ver: PILETTI, Nelson; PRAXEDES, Walter. Dom Helder Câmara: o profeta da paz. - São Paulo: Contexto, 20 Io.
} 
propriedade social dos meios de produção" (apud LIMA, I979, p. I98). O nome do documento era, ao mesmo tempo, uma manifestação de compromisso com os grupos subalternos. Por isso, recebeu o título: "Eu ouvi os clamores do meu povo".

Para termos uma mínima ideia do simbolismo político do documento, é preciso lembrar que quando este foi lançado, a ditadura instaurada contemplava o seu mais frutuoso momento político. Era o ano de 1973. A ditadura colhia os frutos da massiva propaganda ufanista alardeada pelo governo Médici e fomentada pelos resultados supervalorizados no campo econômico, propalados enquanto um "milagre econômico". Segundo pesquisa de José Paulo Netto, houve, de fato, resultados exitosos na economia brasileira do início do "milagre", outubro de I969, até o seu fim, março de I974. Citando alguns números, José Paulo Netto relevou o quadro econômico do país até o fim do ciclo de crescimento econômico da seguinte forma:

[...] a taxa anual de inflação estabilizou-se em torno de 20\%. O PIB per capita aumentou em 51\%; o crescimento econômico se processou a taxas muito altas: 9,5\% em 1969, I0,4\% em 1970, II,3\% em 1971, I2,1\% em 1972 e I4,0\% em 1973. Se a agricultura cresceu, anualmente, em torno de $4 \%$, os números da indústria foram extraordinários [entre] 1968-1973 em todos os setores [...]. E, entre I969 e I974, o valor das exportações saltou de I,9 para 8,o bilhões de dólares [...] (NETTO, 20I4, p. I5I).

Lembremos, contudo, que, para José Paulo Netto, o dito "milagre" não tinha nada de misterioso ou enigmático. Noutras palavras, o "milagre" era produto de um modelo econômico desenvolvido por tecnocratas dos ministérios da Fazenda e do Planejamento, que pode ser resumido, nas conclusões de José Paulo Netto, como composto pelos respectivos elementos: arrocho salarial, concentração de riqueza, garantia de altas taxas de lucros para os monopólios e por uma política governamental que visava atrair empresas transnacionais e fomentar a expansão das subsidiárias já instaladas no país (NETTO, 20I4, p. I53). Ou seja, um "milagre" ilusório, camuflado por um período de boom econômico fugaz, mantendo a superexploração da massa trabalhadora, o arrocho e a concentração de riquezas. Como se viu, nem todos foram beneficiados pelo tal "milagre".

Ainda assim, do início até meados da década de 1970, a ditadura militar gozava de considerável apoio popular e contava com o não menos importante esfacelamento da oposição. A guerrilha estava aniquilada, o movimento estudantil em descenso histórico e a oposição "legal" do Movimento Democrático Brasileiro (MDB) beirava o raquitismo 
eleitoral. Com a supervalorização do "milagre econômico", a oposição perdia ainda mais espaço. Entretanto, quadros expressivos da Igreja Católica sinalizavam para um giro cada vez mais radical à oposição da ditadura. No Nordeste brasileiro, o documento Eu ouvi os clamores do meu povo demonstrava claramente a leitura que parte do episcopado católico da região fazia diante do "milagre econômico". Isso significava que aqueles setores do catolicismo não se curvaram da crítica áspera à política econômica da ditadura, mesmo quando esta vivia o seu auge.

Sobre o "milagre econômico", Eu ouvi os clamores do meu povo questionava ironicamente: “Milagre brasileiro?” (apud LIMA, 1979, p. I85). Pode-se sintetizar a leitura daquele documento acerca do "milagre" na crítica contundente aos efeitos colaterais do tal crescimento econômico na vida concreta dos trabalhadores, especialmente no que se refere à concentração de renda. Nota-se na citação a seguir a narrativa dos bispos que assinaram o documento:

O "milagre brasileiro", despido, de um lado, da crença popular, da devoção e da esperança, resulta de outro lado no favorecimento dos não necessitados, implicando num castigo aos que foram sacrificados, maldição para aqueles que não o pediram. No rastro do "milagre" ficou o empobrecimento relativo e absoluto do povo. A concentração de renda alcançou níveis que exprimem melhor que nada o verdadeiro sentido da política econômica do Governo. Entre 1960 e 1970, 20\% da população brasileira, que constituía a parcela de rendimentos mais altos, aumentou sua participação na renda nacional de $54,4 \%$ para $64,1 \%$, enquanto os $80 \%$ restantes tinham sua participação rebaixada de $45,5 \%$ para $36,8 \%$. A concentração ainda se revela de modo mais gritante quando se considera que, no mesmo período, I\% da população, constituindo o grupo dos mais ricos, aumentou sua participação na renda nacional de $1 \mathrm{I}, 7 \%$ para $17 \%$, enquanto metade da população brasileira, constituída por pessoas de renda mais baixa, teve sua participação reduzida de $17,6 \%$ para $13,7 \%$. A relativa inversão de posições fez com que, em 1970, I\% dos brasileiros passasse a ganhar mais que metade da população brasileira [...] (apud LIMA, 1979, p. I86).

Como se percebe, o documento assinado por pouco mais de quinze sacerdotes católicos, dentre eles o bispo da diocese de Propriá, revelou uma completa dissonância com, à época, o maior galardão da ditadura militar. Era uma prova cabal dos antagonismos 
que cresciam vertiginosamente entre Estado e Igreja. Ademais, vale lembrar o impacto que a Teoria da Dependência exerceu no clero católico mais sintonizado com o processo de mudança. De acordo com Lucelmo Lacerda, teólogos da América Latina foram encontrando na Teoria da Dependência uma explicação plausível para explicar as querelas do continente (LACERDA, 2008, p. 2I). O subdesenvolvimento passou a ser visto por parcela do clero como uma condição estrutural do capitalismo em sua fase imperialista (ibidem) e a sua superação não se resumia na crença desenvolvimentista do avanço do capitalismo, mas em uma completa reforma do sistema.

Desde a sua criação, a diocese de Propriá se empenhou na luta por reformas nas estruturas da sociedade. Identicamente, sempre foi compromisso daquela diocese um envolvimento com os mais pobres. A defesa pela justiça social foi saindo ciclicamente de um estágio moderado-conservador, afinado com o novo regime erguido em 1964, a partir da assimilação cada vez mais contundente das orientações do campo favorável à inserção da Igreja no mundo dos pobres. A ligação da diocese com o movimento de aggiornamento da Igreja Católica somada aos acordos traçados no "Pacto das Catacumbas" e em Medellín facilitou a assimilação. Numas poucas linhas, os antagonismos entre os interesses da diocese de Propriá e os da ditadura militar cresciam na medida em que se radicalizavam as conexões da diocese com a defesa por reformas estruturais capazes de beneficiar as classes subalternas.

É então que, em meados da década de 1970, a diocese passou a ser procurada por pequenos agricultores que eram ameaçados de expulsão das terras da Fazenda Betume por onde estes trabalhavam em regime de meia na produção de arroz -, localizada no município de Neópolis, pela Companhia do Vale do São Francisco (Codevasf). O motivo do conflito apareceu em razão dos interesses estatais que visavam uma "modernização da agricultura" na área. ${ }^{22} \mathrm{O}$ imbróglio em Betume é significativo para compreensão das modificações do comportamento do bispo diocesano e da sua equipe pastoral.

Palavras do próprio dom José Brandão sentenciam a importância da participação da diocese no conflito para a mudança ocorrida em seu comportamento pastoral. Disse o bispo, em entrevista, não haver dúvidas que, o caso Betume, foi o responsável por abrir seus olhos para a tomada de consciência em favor da opção preferencial pelos pobres (apud NASCIMENTO FILHO, 20I7, p. 130). É importante ressaltar que depois do envolvimento da diocese com o caso na Fazenda Betume, amontoaram-se acusações sobre

\footnotetext{
${ }^{22}$ Acerca de maiores detalhes sobre o estopim para o conflito na Fazenda Betume, conferir: FRANÇA, Alex. A Conversão de D. José Brandão de Castro: a ação social de mediadores religiosos na Diocese de Propriá. 2004. Mestrado em Ciências Sociais. Universidade Federal de Pernambuco. Recife, 2004. Ver também: CASTRO, Dom José Brandão de. [Dossiê] o9 de agosto de 1977. Resumo do Caso Betume, Propriá, $4 \mathrm{f}$.
} 
agentes de pastoral diocesanos e também foram levantadas pelos órgãos de vigilância da ditadura variadas informações a respeito das atividades do bispo dom Brandão. ${ }^{23}$ Dito isso, a diocese entrou na segunda metade da década de 1970 emaranhada por uma crescente onda de suspeitas. Vale reiterar que tais suspeitas sobre a diocese existiam desde o início do novo regime apoiado, a princípio, por ela. ${ }^{24}$

A segunda metade da década de 1970 iniciou com o fim do ciclo do "milagre econômico" e com a política de "gradual, mas seguro, aperfeiçoamento democrático [do regime]" (NETTO, 20I4, p I79), naquilo que ficou conhecida como "lenta, gradativa e segura" distensão da ditadura. Era o início do processo que conduziria o país para a redemocratização. Isso não quer dizer que a repressão e a "modernização conservadora" foram abolidas da vida política do país durante a ditadura. O ditador do Brasil no período da distensão, Ernesto Geisel, embora flertando com a abertura da ditadura, não representava uma barreira para a política arbitrária e muito menos um empecilho ante a caça sistemática da ideologia de segurança nacional contra o "inimigo interno" - leia-se, todo aquele que manifestasse posições contrárias à ordem estabelecida. Em concordância com José Paulo Netto, a repressão à “subversão” não tinha em Geisel um adversário; pelo contrário, ela:

constituía mesmo um requisito para o seu projeto de distensão - aniquilar os grupos e partidos que punham radicalmente em questão o regime era uma condição para a nova "institucionalidade" que ele pretendia erguer [...]. O que o separava do [...] "porão" do regime era o seu sentido de hierarquia e autoridade: a sua distensão supunha um aparelho repressivo limitado, disciplinado, subordinado ao poder central, prestando inteira conta da sua atividade e, sobretudo, que não funcionasse como único e/ou principal suporte do regime (NETTO, 20I4, p. I8I. Grifos do autor).

Portanto, o modus operandi do autoritarismo da ditadura não foi anulado, mas passou por um processo de reformulação. A política econômica mantenedora de privilégios também não sofrera desgaste. Mudanças mais radicais ocorriam no seio da

\footnotetext{
${ }^{23}$ Conferir: DOSSIÊ de Dom José Brandão de Castro. Aracaju, [197-]. Arquivo do Departamento De Ordem Política E Social (DOPS), n 770/05. In: Arquivo Público do Estado de Sergipe. Conferir também dossiês de: frei Enoque Salvador de Melo. Aracaju, [19--]. Arquivo do DOPS, no 626/05. In: Arquivo Público do Estado de Sergipe; frei Roberto Eufrásio. Aracaju, [19--]. Arquivo do DOPS, no 627/05. In: Arquivo Público do Estado de Sergipe. Outros agentes de pastoral foram ameaçados e tiveram seus passos vigiados tanto por famílias tradicionais da região quanto por agentes do Estado.

${ }^{24}$ Lembrar o caso citado neste artigo sobre as acusações de comunistas que recaíam sobre os padres vindos da Bélgica que atuavam na diocese de Propriá.
} 
sociedade. Exemplo ilustrativo pode ser verificado na onda de greves operárias e nas vitórias eleitorais do MDB contra a ARENA. Assim, se iniciou a segunda metade da década de 1970. Neste contexto, a diocese de Propriá foi tomada pelo quadro de mudanças eclesiais e políticas que varreram a antiga posição cômoda da diocese ante a ditadura. ${ }^{25}$ Além disso, em meio aos conflitos contra a Codevasf, foi criada em Sergipe a Comissão Pastoral da Terra (CPT). ${ }^{26}$ Dom Brandão passou a estudar a estrutura fundiária da região, na condição de representante da Comissão Pastoral da Terra (CPT) da Regional Nordeste III. ${ }^{27}$

A afinação de dom Brandão com os estudos do sistema fundiário nacional o levou a produzir um dossiê para ser discutido em Brasília. Os resultados do dossiê e da sua fala na Comissão Parlamentar de Inquérito (CPI), em Brasília, resultaram em mais crispações do bispo e de sua diocese frente à ditadura. Isso porque o religioso apontou a existência de uma ampla rede de "grilagem" de terras em cidades da Bahia e de Sergipe. ${ }^{28}$ Uma guerra política entre o bispo e deputados arenistas baianos tinha o seu mais sonoro estopim. ${ }^{29} \mathrm{Na}$ conclusão do acontecimento, foi montada uma CPI para averiguar casos de grilagem de terras nos dois estados.

Guiada pelas suas interpretações sobre a Doutrina Social da Igreja, cada vez mais radicalizadas, a diocese de Propriá acumulava adversários - quando não inimigos - e as atividades do seu bispo eram assim descritas pela comunidade de informações da ditadura:

[...] em suas palestras, ia de encontro ao regime do país e em seus pronunciamentos, verificou-se que ele deixava transparecer suas tendências esquerdistas. Instigou aos colonos de Propriá, que trabalhavam para a CODEVASF, a não deixarem as propriedades desapropriadas pela CODEVASF, alegando injustiça em suas avaliações - os quais (colonos)

\footnotetext{
${ }^{25}$ Alguns exemplos: (I) a chegada de religiosos sintonizados com a opção preferencial pelos pobres no início dos anos I970; (2) a formação das primeiras comunidades eclesiais de base (CEBs); (3) a leitura bíblica à luz da Teologia da Libertação; e (4) a intensificação da diocese nas lutas políticas da região. Para maiores detalhes sobre o processo de radicalização, conferir: SANTOS, Osnar. O confronto da fé ante o escândalo da pobreza: a emergência da opção preferencial pelos pobres na Diocese de Propriá/SE (I968-1979). Mestrado em História. Universidade Federal de Alagoas. Maceió, 2017.

${ }^{26}$ Segundo fala de dom José Brandão, em palestra para a Assembleia Legislativa de Sergipe, a CPT surgiu na Bahia e em Sergipe, depois de um dia de estudos, num encontro em Salvador, a I5 de janeiro de I976, quando um expositor [...] focalizou a realidade rural dos dois estados. Parte da sua fala salientou a surpresa que atacou os participantes do encontro quando ouviram falar pela primeira vez na "grilagem" de terras. Cf. CASTRO, Dom José Brandão de. [Palestra] o2 de setembro de 1977. A Igreja no Brasil de Hoje e a Pastoral da Terra, Propriá, 5 f.

${ }^{27}$ Bahia e Sergipe são os estados pertencentes a Regional Nordeste III.

${ }^{28}$ A grilagem de terras é uma prática ilegal e ocorre quando algum indivíduo ou grupo social envelhece documentos forjados para tomar posse de determinada área de terra. Até os dias de hoje, grandes proprietários se utilizam do ilícito esquema para o acúmulo de terras.

${ }^{29}$ Para maiores detalhes sobre o imbróglio entre bispo e deputados da ARENA da Bahia, ver: GRILAGEM: esforço arenista para obstruir CPI. In: Tribuna da Bahia, I2 de maio de I977, p. 2.
} 
estariam dispostos a uma resistência armada e que essa atitude seria a resultante da ação do Bispo de Propriá e outros Padres, através do manifesto distribuído nas fazendas de Propriá, por meio de panfleto [...]. Como Bispo de Propriá, foi acusado por dois deputados de Salvador de ser Comunista. $^{30}$

A ordem estabelecida no pós-golpe de 1964 pelo complô empresarial-militar e coordenada pela elite orgânica do bloco de poder do capital multinacional e associado se voltou contra setores da sociedade civil que estiveram, em algum momento, sintonizados com a derrubada do governo Jango e que legitimaram certas disposições da ditadura por um período considerável. A diocese de Propriá fazia claramente parte daqueles setores. As antigas crenças nas instâncias do Estado se esvaziavam paulatinamente e a instituição religiosa passava a desempenhar na cena política sergipana e nacional um papel de notória oposição ao establishment.

Não à toa que adversários da inclinação da diocese de Propriá ao campo radical do catolicismo surgiram dentro da própria Igreja em Sergipe. Caso mais emblemático se expressou na figura do arcebispo metropolitano de Aracaju, dom Luciano Cabral Duarte. Conforme apontou a pesquisa do historiador Paulo César Gomes, dom Luciano chegou mesmo a enviar correspondência ao núncio apostólico no Brasil, dom Carmine Rocco, o informando sobre suas suspeitas acerca do ato de desagravo que ocorreu na cidade de Propriá no dia 17 de agosto de I980 (GOMES, 20I4, p. 272). Para dom Luciano, o ato tinha conotação nitidamente político-partidária e que pessoas por lá presentes o teriam informado sobre os discursos que pontuavam a necessidade de "derrubar o regime".

De fato, houve um ato de desagravo no ano de 1980 em decorrência das ameaças sofridas por dom Brandão e seus agentes de pastoral. Igualmente, no limiar da década de I980, já era nítida as condenações da diocese no tocante à ditadura. Isso se expôs indiretamente na matéria acerca do assassinato do arcebispo de San Salvador, dom Oscar Romero. A matéria de A Defesa, a muito distante do tom moderado do início da década de I970, deu destaque ao perfil de dom Romero, sob o título: "Quem era o bispo assassinado [?]”. Por lá, sentenciou: "Nesse país o povo vive oprimido por um regime de exploração, como infelizmente acontece em toda América Latina". ${ }^{31}$

Críticas mais diretas às formas de reprodução das arbitrariedades de famílias tradicionais e de aparatos policiais foram expressas em diversas ocasiões, ainda na década

\footnotetext{
${ }^{30}$ Dossiê de Dom José Brandão de Castro. Aracaju, [197-]. Arquivo do Departamento De Ordem Política E Social (DOPS), nº 770/05. In: Arquivo Público do Estado de Sergipe.

${ }^{31}$ Cf. "QUEM era o bispo assassinado". In: A Defesa, 20 de abril de I98o, p. 4.
} 
de 1970. É sintomática, a título de exemplo, a comunicação direta de dom Brandão com o governador Augusto Franco no caso referente ao sequestro de duas freiras diocesanas. Para dom Brandão, poderia ser mais exitoso se queixar diretamente com o governador do que apelar para a polícia, dado que esta estaria comprometida com o poder dos oligarcas da região. ${ }^{32}$

Mediadora de conflitos e com suas expressões, a exemplo das CEBs e da CPT, cada vez mais aliadas das classes subalternas no Estado, a diocese de Propriá estimulou, no processo de redemocratização, a criação de sindicatos e deu espaço em suas fileiras para a formação do Partido dos Trabalhadores (PT) e do Movimento dos Trabalhadores Rurais Sem-Terra (MST). Estava ela, daquela forma, cumprindo requisitos fundamentais do movimento do cristianismo da libertação: dar autonomia e protagonismo aos movimentos de inspiração cristã. Atuando junto destes movimentos, as relações entre a diocese de Propriá e as classes dominantes saíram da seara amistosa para um ciclo tétrico de animosidades. Alguns dos conflitos foram apontados pelos pesquisadores Solimar Bonjardim e Maria de Almeida. Eram os do:

[...] Betume (Neópolis), da Fazenda Santana dos Frades (Pacatuba), e do Mundeú da Onça (Neópolis); do povo indígena Xocó da Ilha de São Pedro e da Caiçara (Porto da Folha); dos sem-terra da Barra da Onça e Pedras Grandes (Poço Redondo), da Ilha do Ouro (em Porto da Folha), Monte Santo (Gararu) e Morro dos Chaves (Propriá); e a defesa da terra das comunidades quilombolas do São Francisco Sergipano (BONJARDIM; ALMEIDA, 2013, p. I70-I7I).

Uma das soluções encontradas pelas elites da região foi requerer às autoridades religiosas a expulsão do bispo da região do baixo São Francisco. ${ }^{33}$ Outras saídas menos sofisticadas também foram dirigidas em refutação às ações da diocese. Ameaças de morte e espancamento, assédio moral, sequestros e tentativas de assassinato por encomenda faziam parte do cardápio de grandes proprietários de terra e autoridades regionais - que contavam, em muitas ocasiões, com a conivência do Estado, como agentes da Polícia

\footnotetext{
${ }^{32}$ Cf. BISPO denuncia tentativa de sequestro de duas freiras em Sergipe e acusa família. Não foi encontrada a data da matéria, nem mesmo o nome do jornal, apenas o informe Caderno Nacional, p. 2I. Mas sabe-se que o caso ocorreu no final da década de 1970, em meio aos conflitos entre os indígenas xocó, defendidos pela diocese, e a família Britto, detentora de grande porcentagem de terras na região do Baixo São Francisco.

${ }^{33} \mathrm{O}$ caso ganhou repercussão nacional. Cf. BISPO enfrenta pressões e acusa a política de terras. In: A Tarde, IO de novembro de 1978. Ver também: PREFEITOS sergipanos vão pedir saída do bispo. In: $O$ Globo, o8 de novembro de 1978 .
} 
Federal (PF) e autoridades policiais - contra a diocese. ${ }^{34}$ Essa era parte do cenário encontrado pela diocese no período de redemocratização. Como se percebe, um cenário nada tranquilo.

Com a democracia, em tese, restabelecida, no ano de 1985, a diocese manteve seus laços umbilicais com os movimentos que surgiam sob o forte estímulo da instituição. Entrevistas e matérias sobre as organizações autônomas à hierarquia eclesial, como o PT e o MST, eram difundidas por A Defesa. O espaço dado às novas lideranças políticas que emergiam nesse processo era evidente. ${ }^{35}$ Entretanto, o cerco erguido contra a diocese por suas atividades não ganhou repouso. Pelo contrário, o envolvimento da diocese com as lutas permaneceu, sofrendo um de seus maiores baques com a aposentadoria do bispo dom Brandão. Acerca deste caso, é unânime entre antigos agentes de pastoral a existência de um complô responsável pela aposentadoria do bispo dom Brandão - oito anos antes da idade canônica para aposento. ${ }^{36}$

\section{Considerações finais}

As atuações da diocese de Propriá até o processo de redemocratização revelam a importância em examinar as múltiplas manifestações da Igreja Católica no país durante aquele período. Com isso, a excessiva centralidade dada às regiões teoricamente mais expressivas do país, que resulta em generalizações sobre o Brasil, tende a desaparecer. A diocese de Propriá chegou à redemocratização imbuída por singularidades não vistas em outras dioceses no país. O seu processo de mudança é significativamente digno de uma rígida avaliação.

Evidente que este artigo não buscou compreender os meandros de toda a trajetória da diocese até a aposentadoria do bispo dom Brandão - sem dúvidas, um dos principais ataques sofridos pela instituição. Mas procurou aclarar, resumidamente, exemplos da sua inclinação ao campo radical do catolicismo. Esse objetivo foi fundamental para o principal escopo deste artigo, tão somente analisar como essa nova maneira de agir se comportou no

\footnotetext{
${ }^{34}$ Conferir o caso da invasão de missa dominical realizada por membros da família Britto. Por lá, ocorreu uma agressão ao agente de pastoral Fábio Alves dos Santos e ameaças de morte dirigidas contra os sacerdotes Enoque Salvador de Melo e Nestor Mathieu. Em: FIÉIS ameaçados e missa interrompida. In: Jornal de Sergipe, 28 de novembro de 1978. Outras matérias de jornais sergipanos e de outros estados noticiaram as ameaças sofridas pela equipe diocesana.

${ }^{35}$ A título de exemplo, ver entrevista concedida pelo jovem político Marcelo Déda - que viria a ser um dos principais quadros do PT nacionalmente - ao jornal A Defesa, datada de janeiro de 1987, p. 4 .

${ }^{36}$ A esse respeito, cf. OLIVEIRA, Roberto. Caminhando com Jesus: uma experiência missionária no Nordeste. - João Pessoa: Ideia, 2006. Ver também: COMBLIN, José. [Correspondência] I4 de setembro de I985, São Paulo [para] Dom José Brandão de Castro, Propriá, 2f.
} 
processo de redemocratização do país, estimulando desde movimentos que eram ligados à diocese, mas que agiam com muita autonomia, como a CPT, até aqueles totalmente independentes da hierarquia, como o MST e o PT. Vale dizer, organizações que até os dias atuais se caracterizam enquanto representações de grande vulto no debate político e social do país.

\section{Referências bibliográficas}

ALMEIDA, Adjovanes Thadeu Silva de. O regime militar em festa: a comemoração do Sesquicentenário da Independência brasileira (1972). Doutorado em História. Universidade Federal do Rio de Janeiro. Rio de Janeiro, 2009.

BEOZZO, José. Pacto das Catacumbas: por uma Igreja serva e pobre. São Paulo: Paulinas, 2015. BONJARDIM, Solimar; ALMEIDA, Maria. Tradição e Luta pela terra: a Diocese de Propriá e o fortalecimento da identidade católica. Revista GEONORDESTE, São Cristóvão, n. I, p. I62-I79, 2013.

CASTRO, Dom José Brandão de. [Dossiê] o9 de agosto de 1977. Resumo do Caso Betume, Propriá, 4f.

[Palestra] 02 de setembro de 1977. A Igreja no Brasil de Hoje e a Pastoral da Terra, Propriá, $5 f$.

COMBLIN, José. [Correspondência] I4 de setembro de I985, São Paulo [para] Dom José Brandão de Castro, Propriá, 2f.

CONCLUSÕES DE MEDELLÍN. II Conferência do Episcopado Latino-americano. São Paulo: Paulinas, 1968.

DANTAS, Ibarê. A tutela militar em Sergipe: 1964-1984 (partidos e eleições num Estado autoritário). São Cristóvão: Editora UFS, 20I4.

DOSSIÊ de Dom José Brandão de Castro. Aracaju, [197-]. Arquivo do Departamento De Ordem Política E Social (DOPS), nº 770/05. In: Arquivo Público do Estado de Sergipe.

DOSSIÊ de frei Enoque Salvador de Melo. Aracaju, [19--]. Arquivo do Departamento De Ordem Política E Social (DOPS), nº 626/05. In: Arquivo Público do Estado de Sergipe.

DOSSIÊ de frei Roberto Eufrásio de Oliveira. Aracaju, [19--]. Arquivo do Departamento De Ordem Política E Social (DOPS), nº 627/05. In: Arquivo Público do Estado de Sergipe.

DREIFUSS, René. 1964, a conquista do Estado. Petrópolis: Vozes, I98I.

DUARTE, Luciano. A Igreja às portas do ano 200o. Aracaju: Secretaria de Estado da Cultura e Meio Ambiente, 1989.

FAUSTO, Bóris. História do Brasil. São Paulo: Editora da Universidade de São Paulo, I995. 
FRANÇA, Alex. A Conversão de D. José Brandão de Castro: a ação social de mediadores religiosos na Diocese de Propriá. 2004. Mestrado em Ciências Sociais. Universidade Federal de Pernambuco. Recife, 2004.

GOMES, Paulo César. Os bispos católicos e a ditadura militar brasileira: a visão da espionagem. Rio de Janeiro: Multifoco, 2014.

LACERDA, Lucelmo. Uma análise da polêmica em torno do livro "Igreja: Carisma e Poder", de Leonardo Boff, na Arquidiocese do Rio de Janeiro. Mestrado em História. Pontifícia Universidade Católica de São Paulo, São Paulo, 2008.

LIBÂNIO, João. Igreja contemporânea - Encontro com a modernidade. São Paulo: Loyola, 200. LIMA, Luiz. Evolução Política dos Católicos e da Igreja no Brasil: hipóteses para uma interpretação. Petrópolis: Vozes, 1979.

LÖWY, Michael. A guerra dos deuses: religião e política na América Latina. Petrópolis: Vozes, 2000.

MAINWARING, Scott. Igreja Católica e política no Brasil (I9I6-I985). São Paulo: Brasiliense, 2004 .

MOTTA, Rodrigo. A “Indústria” do Anticomunismo. Revista de Pós-Graduação em História da Universidade Federal do Rio Grande do Sul, Porto Alegre, v. 09, n. I5, p. 7I-9I, 200 I.

A modernização autoritário-conservadora nas universidades e a influência da cultura política. In: AARÃO REIS, Daniel et al. A ditadura que mudou o Brasil: 50 anos do golpe de I964. Rio de Janeiro: Zahar, 2014.

NASCIMENTO FILHO, Isaías. Dom Brandão: um pastor com cheiro de ovelhas. Belo Horizonte: O Lutador, 2017.

NETTO, José. Pequena história da ditadura brasileira (1964-1985). São Paulo: Cortez, 2014.

OLIVEIRA, Roberto. Caminhando com Jesus: uma experiência missionária no Nordeste. - João Pessoa: Ideia, 2006.

PILETTI, Nelson; PRAXEDES, Walter. Dom Helder Câmara: o profeta da paz. São Paulo: Contexto, 2010.

REZENDE, Maria. A ditadura militar no Brasil: repressão e pretensão de legitimidade: 1964-I984. - Londrina: Eduel, 2013.

SANTOS, Osnar. O confronto da fé ante o escândalo da pobreza: a emergência da opção preferencial pelos pobres na Diocese de Propriá/SE (1968-1979). Mestrado em História. Universidade Federal de Alagoas. Maceió, 2017.

SILVA, Vicente. A Aliança para o Progresso no Brasil: de propaganda anticomunista a instrumento de intervenção política (I96I-1964). Mestrado em História. Universidade Federal do Rio Grande do Sul, Porto Alegre, 2008. 
TEIXEIRA DA SILVA, Francisco. Do golpe militar à redemocratização (I964/1984). In: LINHARES, Maria et al. História Geral do Brasil. Rio de Janeiro: Campus, I990, p. 35I-376.

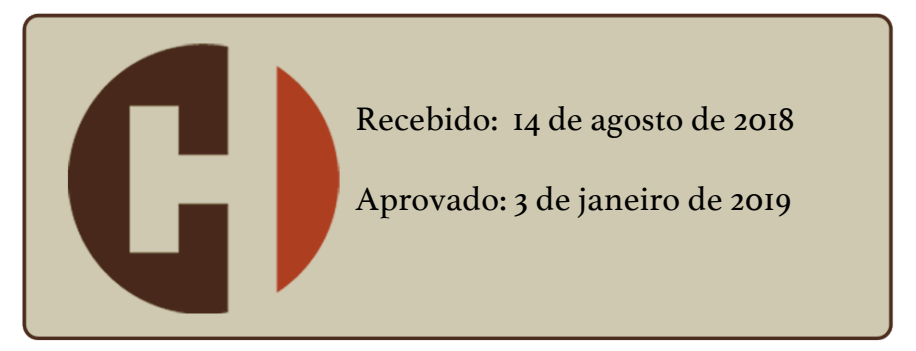

